\title{
TWO DIRECT SIMPLE VISIBLE SPECTROPHOTOMETRIC ASSAY METHODS OF SOLIFENACIN SUCCINATE IN ORAL TABLET FORMULATIONS
}

\author{
M. Madhu Kiran ${ }^{1, *}$ and C. Rambabu ${ }^{2}$ \\ $1^{*}$ Department of Chemistry, Acharya Nagarjuna University, Guntur,A.P,India \\ ${ }^{2}$ Department of Chemistry, Acharya Nagarjuna University, Guntur,A.P,India \\ *E-mail: svm2032@gmail.com
}

\begin{abstract}
Two direct, simple visible spectrophotometric methods (Method -I \& II) were described for the assay of solifenacin succinate in pure and in oral dosage forms. The proposed methods (I\&II) are based on the ion association complex reactions between the mentioned drug (solifenacin succinate) and the basic dyes (Methylene blue and Methylene Violet) respectively. Beer-Lambert plots showed good correlation in the concentration range of $2.0-10 \mu \mathrm{g} / \mathrm{mL}$ for methods-I \&II respectively. The proposed methods were applied to commercially available dosage forms (tablets) of solifenacin succinate and the results were statistically compared with the results obtained by the reported $\operatorname{method}^{7}$ with recovery studies. The proposed methods offered the advantages of being simple and economical that can be applied without the need for expensive instrumentation and reagents in quality control analysis.
\end{abstract}

Keywords: Solifenacin succinate, Visible spectrophotometry, Method validation.

@) RASĀYAN. All rights reserved

\section{INTRODUCTION}

Solifenacin succinate ${ }^{1-3}$ (Fig.-1), a competitive muscarinic acetylcholine receptor antagonist used for the treatment of overactive bladder with or without urinary incontinence. Being an antagonist, it prevents the binding of acetylcholine to M3 receptor subtype thereby reducing smooth muscle tone in the bladder, thereby allowing the bladder to retain larger volumes of urine and reducing the number of incontinence episodes.

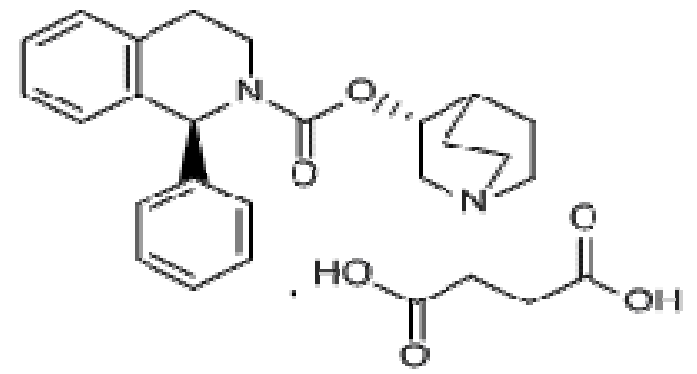

Fig.-1: Chemical Structure of Solifenacin succinate

Monograph for solifenacin succinate is available only in European Pharmacopoeia ${ }^{4}$. Chemically, Solifenacin succinate is butanedioic acid (3R)-1-azabicyclo [2.2.2] octane-3-yl(1S)-1-phenyl-1,2,3,4tetrahydroisoquinoline-2-carboxylate with an empirical formula of $\mathrm{C}_{27} \mathrm{H}_{32} \mathrm{~N}_{2} \mathrm{O}_{6}$ and molecular weight of $480.5528 \mathrm{gms} / \mathrm{mol}$. It is freely soluble in water, Glacial acetic acid, dimethyl sulfoxide and methanol. Presently six brands of generics of solifenacin succinate are available in local pharmacy that is formulated for oral administration. In the current study for one commercial formulation of solifenacin succinate in the brand name of BISPEC (Dr.Reddy Laboratories Ltd;Dosage strengths -10mg) was used . 
Literature survey revealed only three spectrophotometric methods $s^{5-7}$ were reported to the present date for the determination of solifenacin succinate in tablet dosage forms. As such no attention was made in developing new visible spectrophotometric methods by exploiting the analytically useful functional groups present in solifenacin succinate.In this direction, the author made an attempt to develop economically viable visible spectrophotometric assay methods for solifenacin succinate in its tablet formulations. Accordingly, the author developed two new, simple visible spectrophotometric methods for the assay of solifenacin succinate in tablet formulations.

\section{EXPERIMENTAL}

Material and Methods

In the present study UV - Visible digital spectrophotometer [Model SL-157,Elico] along with 1.0cm matched quartz cells were used for the spectral measurements. A Systronics digital pH meter [Model361] was used for $\mathrm{pH}$ measurements.

\section{Reagents Preparation}

The reagents used in this assay are of analytical grade and the reagent solutions were prepared using double distilled water.

Method -I [Methylene Blue; MB (0.1\% W/V)]

Prepared by dissolving, accurately weighed $100 \mathrm{mg}$ of Methylene Blue (MB) reagent in $100 \mathrm{ml}$ of distilled water and subsequently washed with chloroform to remove chloroform soluble impurities.

Method - II [Methylene Violet; MV (0.1\% W/V)]

Prepared by dissolving $100 \mathrm{mg}$ of Methylene Violet (MV) reagent in $100 \mathrm{ml}$ of distilled water and subsequently washed with chloroform to remove chloroform soluble impurities

\section{Preparation of Standard Drug Solutions}

A $1.0 \mathrm{mg} / \mathrm{ml}$ solution was prepared by dissolving $100 \mathrm{mg}$ of pure solifenacin succinate $(99 \%)$ in $100 \mathrm{ml}$ of methanol and this stock solution was diluted step wise with distilled water to get the working standard solutions of solifenacin succinate with concentrations of $40 \mu \mathrm{g} / \mathrm{ml}$ for Methods-I and II respectively.

\section{Assay of Oral Dosage Formulations}

Accurately weighed a portion of finely ground oral tablet powder (BISPEC-10mg) equivalent to 100mg of solifenacin succinate was carefully transferred into a $100 \mathrm{ml}$ volumetric flask. Add $80 \mathrm{ml}$ of methanol to the same flask, and shaken well for $20 \mathrm{~min}$. Later the contents were diluted up to the mark with methanol and filtered through Whatman filter paper No 41. This filtrate was evaporated to dryness to obtain drug residue and was finally dissolved as described in standard solution preparation. These solutions were analyzed as under recommended procedures described.

\section{Recommended Procedure}

After several experimental trials and studies of various parameters involved, the following procedures were recommended for the assay of solifenacin succinate in pure and in formulations.

\section{Method-I}

Aliquots of working standard drug solution $(0.5-2.5 \mathrm{ml}, 40 \mu \mathrm{g} / \mathrm{ml})$ were placed separately into a series of $125 \mathrm{ml}$ separating funnels and $1.0 \mathrm{ml}$ of $\mathrm{pH} 9.8$ buffer solution was added. To above funnels $1.0 \mathrm{ml}$ of methylene blue (MB) solution was added and the total volume of aqueous phase was adjusted to $10 \mathrm{ml}$ with distilled water. To the above funnels $10 \mathrm{ml}$ of chloroform was added and the contents were mixed thoroughly with intermittent shaking for $2 \mathrm{~min}$. Later, the organic colored layer (chloroform) was collected and the absorbance was measured at $615 \mathrm{~nm}$ against reagent blank. The amount of drug present was obtained using Beer's Lambert plot. (Fig.-4). 


\section{Method-II}

Aliquots of standard drug solution $(0.5-2.5 \mathrm{ml}, 40 \mu \mathrm{g} / \mathrm{ml})$ were placed separately into a series of $125 \mathrm{ml}$ separating funnels and $1.0 \mathrm{ml}$ of $\mathrm{pH} 9.8$ buffer solution were added. To above funnels $1.0 \mathrm{ml}$ of methylene violet (MV) reagent solution was added and the total volume of aqueous phase was adjusted to $10 \mathrm{ml}$ with distilled water. Then $10 \mathrm{ml}$ of chloroform was added in each separating funnel and the contents were mixed by shaking for 2 mins respectively. The organic colored layer was collected and the absorbance was measured at $620 \mathrm{~nm}$ against a reagent blank(Chloroform). The amount of drug present was deduced using Beer's Lambert plot. (Fig.-5).

\section{Optimization of experimental conditions}

\section{RESULTS AND DISCUSSION}

Preliminary experimental trials were carried out by the author in this accord in the developing procedures for the new methods (I and II) spectrophotometrically by observing and studying the effects produced on the absorbance of the colored species obtained by changing one parameter and keeping the other parameters fixed.

\section{Method-I and II}

The optimum conditions in these methods were made based on the study of the effects on absorbance values with the use of various parameters such as the type of acid for the buffer, conc. of dye MB (Method-I), or MV (Method-II), choice of organic solvent, shaking time and the stability of the colored species and the results are incorporated in Table-1.

Table -1: Optimum conditions established for methods-I \& II for solifenacin succinate

\begin{tabular}{|c|c|c|c|}
\hline Parameter used & Optimum Range & Conditions in Procedure & Observation \\
\hline $\begin{array}{l}\lambda_{\max } \text { in } \mathrm{nm} \text { for methods } \\
\text { I \& II }\end{array}$ & $\begin{array}{l}610-620 \mathrm{~nm} \\
610-630 \mathrm{~nm}\end{array}$ & $\begin{array}{l}615 \mathrm{~nm} \\
620 \mathrm{~nm}\end{array}$ & -- \\
\hline $\begin{array}{l}\text { Effect of buffer on color } \\
\text { development }\end{array}$ & $9.0-10.0$ & pH-9.8 & $\begin{array}{l}\text { Variations of the } \mathrm{pH}<9.0 \\
\text { and }>9.8 \text { resulted in low } \\
\text { absorbance values }\end{array}$ \\
\hline $\begin{array}{l}\text { Volume in } \mathrm{ml} \text { of buffer } \\
\text { needed for maximum } \\
\text { color intensity }\end{array}$ & $0.5-1.5$ & $1.0 \mathrm{~mL}$ & $\begin{array}{l}\text { Optimum volume of } \\
1.0 \mathrm{ml} \text { of buffer was } \\
\text { sufficient for maximum } \\
\text { color development }\end{array}$ \\
\hline $\begin{array}{l}\text { Volume in ml of reagent } \\
\text { solution } \\
\text { MB (Method-I) } \\
\text { MV(Method-II) }\end{array}$ & $\begin{array}{l}0.1-1.0 \\
0.1-1.0\end{array}$ & $1.0 \mathrm{~mL}$ & $\begin{array}{l}1.0 \mathrm{ml} \text { of } \mathrm{MB} \text { and } \mathrm{MV} \\
\text { were necessary to obtain } \\
\text { broad range of beer's law } \\
\text { limits }\end{array}$ \\
\hline $\begin{array}{l}\text { Choice of organic } \\
\text { solvents for extraction of } \\
\text { colored complex }\end{array}$ & $\begin{array}{l}\text { Chloroform, } \\
\text { Methanol }\end{array}$ & Chloroform & $\begin{array}{lr}\begin{array}{l}\text { Chloroform } \\
\text { preferred as }\end{array} \\
\begin{array}{l}\text { colored } \\
\text { complex }\end{array} & \\
\end{array}$ \\
\hline $\begin{array}{l}\text { Effect of shaking time } \\
(\mathrm{min})\end{array}$ & $1-5$ & 2 & $\begin{array}{l}\text { Constant absorbance } \\
\text { values were obtained for } \\
\text { the shaking period of } 2 \\
\text { min. }\end{array}$ \\
\hline $\begin{array}{l}\text { Stability of the colored } \\
\text { species }\end{array}$ & ----- & $12 \mathrm{hrs}$ & ---- \\
\hline
\end{tabular}

\section{Spectral Characteristics}

After establishing optimized conditions in each developed methods (I and II) with specified amounts of solifenacin succinate was analyzed separately by following the above procedures and the colored products 
RASĀYAN J. Chem.

Vol. 10 | No. 4 |1068-1074 | October - December | 2017

were scanned in the wavelength region of 340 to $900 \mathrm{~nm}$ against reagent blank. The absorbance's for each developed method was recorded and were graphically reported under Fig.-2 for Method-I and Fig. -3 for Method-II respectively.

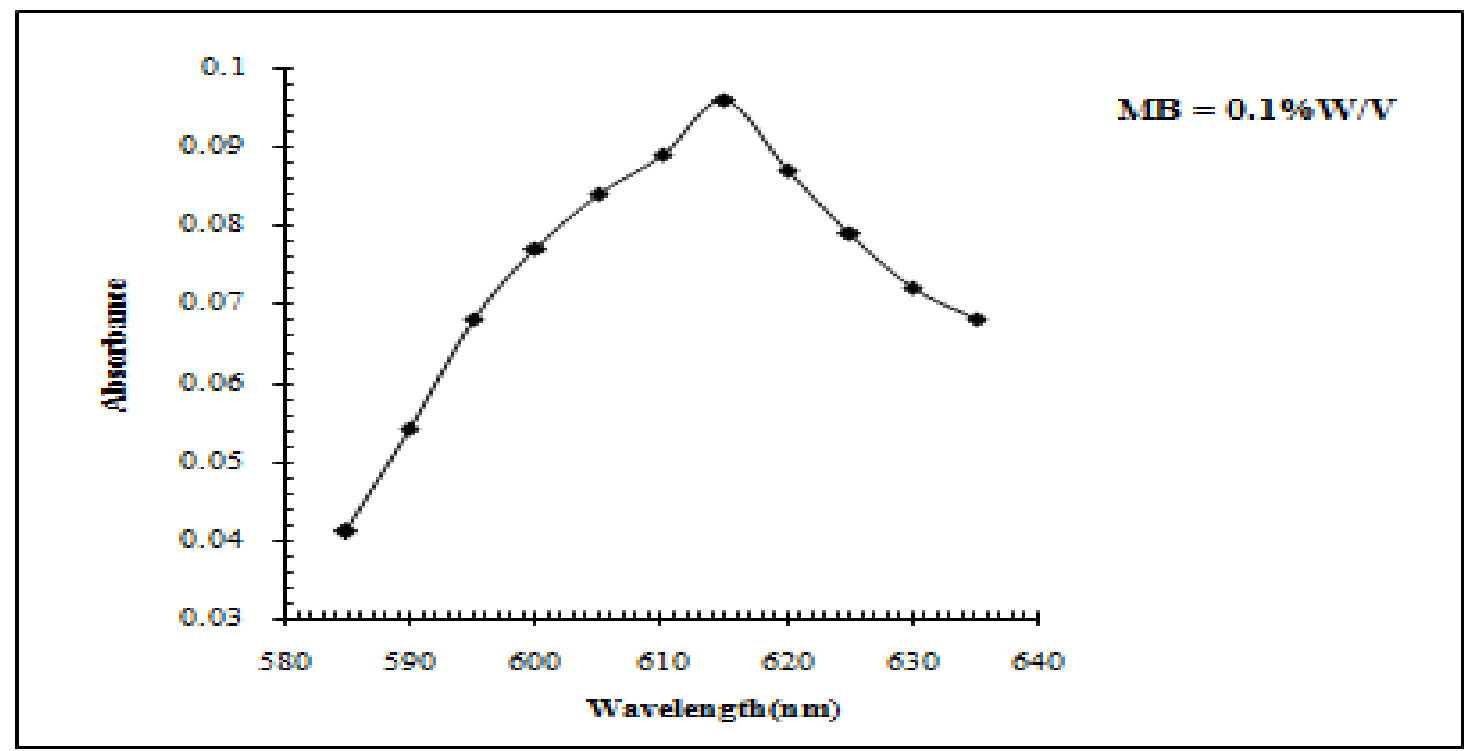

Fig.-2: Absorption spectra of solifenacin succinate for Method-I

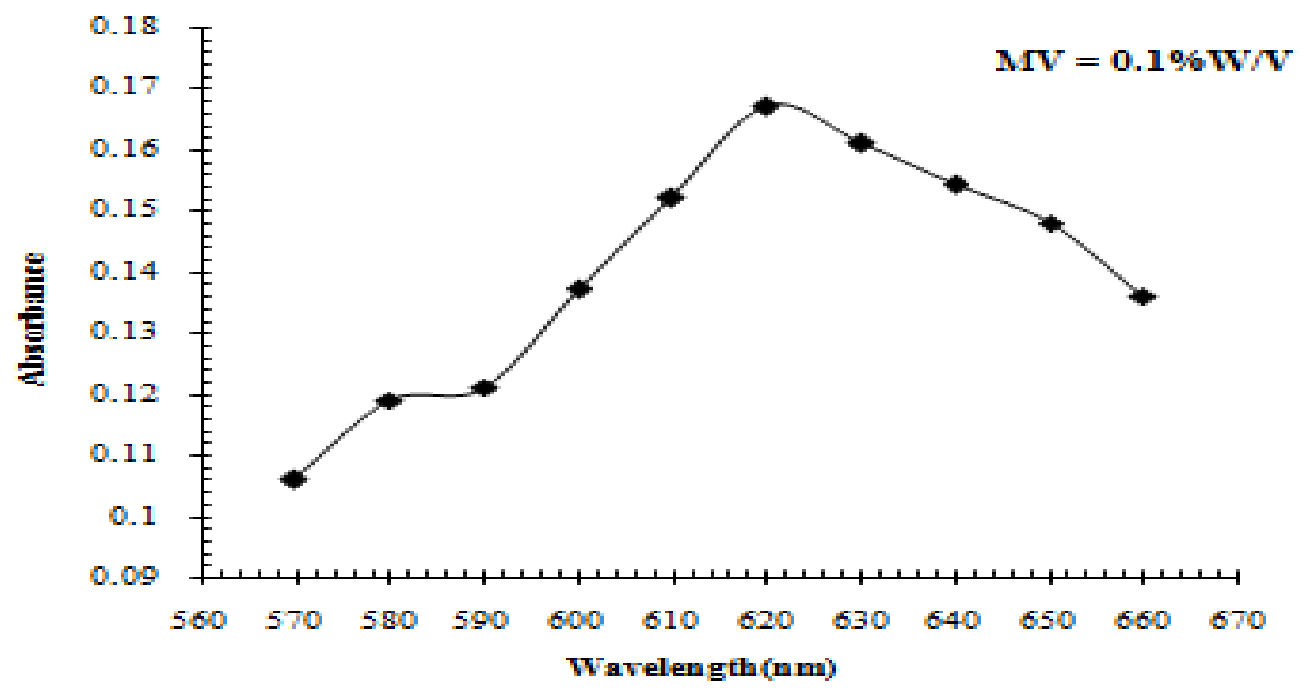

Fig.-3: Absorption spectra of solifenacin succinate for Method-II

\section{Optical Characteristics}

Standard solutions containing solifenacin succinate in each linearity level were prepared and were analyzed at their maximum absorption $\left(\lambda_{\max }\right)$ for each developed method. Calibration graphs were obtained by plotting absorbance obtained versus the concentration of the drug and their results were deduced by least squares regression analysis. The Beer's law plots of solifenacin succinate in each developed method were recorded graphically (Fig.-4 and 5) and their spectral results [i.e, slope, intercept, correlation, Beer's law limits, molar absorptivity, Sandell's sensitivity and optimum photometric range] were calculated and are reported in Table-2 respectively. The LOD and LOQ values for solifenacin succinate for the developed methods were determined and are reported in Table- 2 . 
RASĀYAN J. Chem.

Vol. 10 | No. 4 |1068-1074 | October - December | 2017

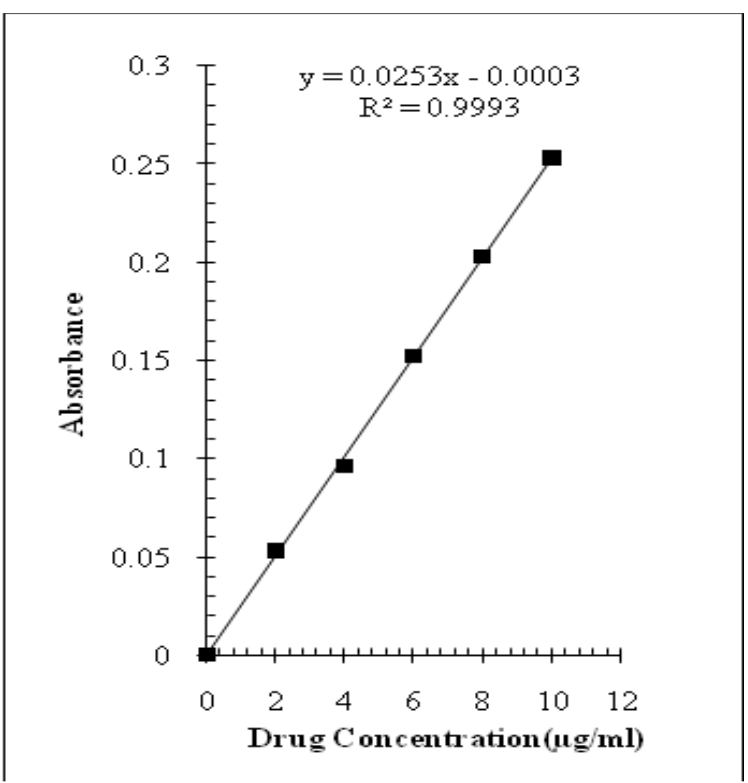

Fig.-4: Beer's law spectra of solifenacin succinate for Method-I

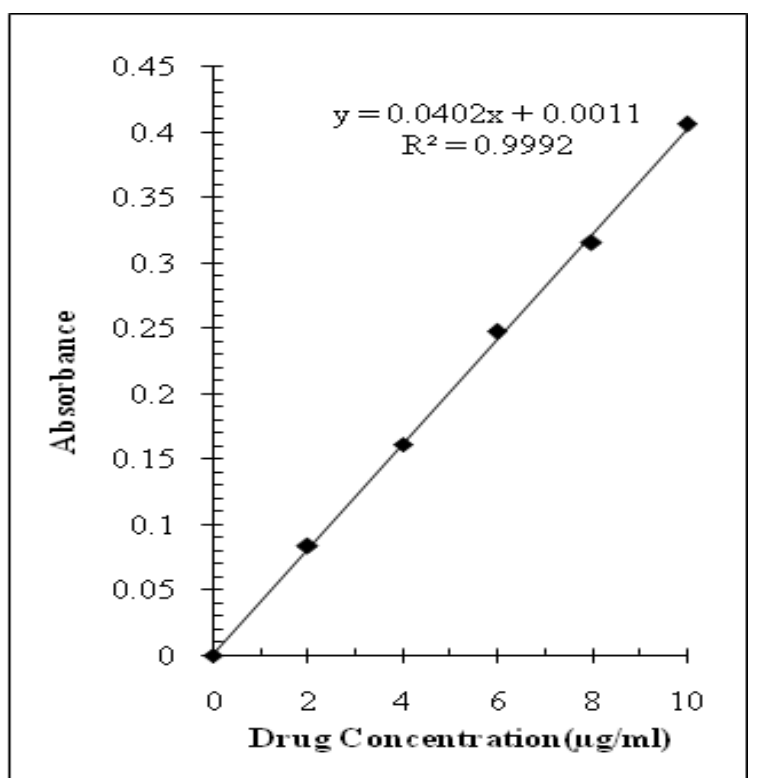

Fig.-5: Beer's law spectra of solifenacin succinate for Method-II

\section{Precision}

The precision for the two developed methods (I and II) was evaluated from the absorbance's values obtained by assaying of six replicates of a fixed amount of solifenacin succinate working standard solution in total solution. The percent of relative standard deviation and percent range of error (at 0.05 and 0.01 confidence limits) were calculated and are represented in Table-2.

\section{Accuracy}

The accuracy of the proposed methods (I and II) was determined by analyzing different amounts of bulk samples of solifenacin succinate within the Beer's law limits and the percentage of analyte recovered. The accuracy results (percent error) for the two developed methods were reported in Table-2.

Table-2: Results of optical and regression parameters of the proposed methods (I and II)

\begin{tabular}{l|c|c}
\hline Parameter & Method-I & Method-II \\
\hline$\lambda_{\max }(\mathrm{nm})$ & 615 & 620 \\
\hline Beer's law limits $(\mu \mathrm{g} / \mathrm{mL})$ & $2.0-10.0$ & $2.0-10.0$ \\
\hline Molar absorptivity $\left(1 \mathrm{~mol}^{-1} . \mathrm{cm}^{-1}\right)$ & $7.164 \times 10^{3}$ & $1.201 \times 10^{4}$ \\
\hline Sandell's sensitivity $\left(\mu \mathrm{g} \cdot \mathrm{cm}^{-2} / 0.001\right.$ absorbance unit $)$ & 0.3466 & 0.2917 \\
\hline Optimum photometric range $(\mu \mathrm{g} / \mathrm{mL})$ & $3.0-9.0$ & $3.5-8.5$ \\
\hline Regression equation $(\mathrm{Y}=\mathrm{a}+\mathrm{bc}) ; \mathrm{slope}(\mathrm{b})$ & 0.0253 & 0.0402 \\
\hline Intercept $(\mathrm{a})$ & 0.0030 & 0.00112 \\
\hline Correlation Coefficient $(\mathrm{r})$ & 0.9993 & 0.9992 \\
\hline Standard Deviation on Intercept $\left(\mathrm{S}_{\mathrm{a}}\right)$ & 0.00344 & 0.00478 \\
\hline Standard Deviation on Slope $\left(\mathrm{S}_{\mathrm{b}}\right)$ & 0.000518 & 0.000721 \\
\hline Standard error on Estimation $\left(\mathrm{S}_{\mathrm{e}}\right)$ & 0.00328 & 0.00456 \\
\hline LOD $(\mu \mathrm{g} / \mathrm{mL})$ & 0.407 & 0.364 \\
\hline LOQ $(\mu \mathrm{g} / \mathrm{mL})$ & 1.35 & 1.18 \\
\hline Relative Standard Deviation $(\%)^{*}$ & 1.067 & 1.165 \\
\hline 0.05 level & 0.892 & 0.974 \\
\hline 0.01 level & 1.320 & 1.441 \\
\hline
\end{tabular}

* Average of six determinations 


\section{Analysis of Market Formulations}

Commercial formulation (BISPEC tablets-10mg) of solifenacin succinate was successfully analyzed by the two new proposed methods. The values obtained for formulations by the proposed methods were compared statistically with $\mathrm{F}$ and t-test with the reported method $^{7}$ and was found no significant difference respectively and the results were incorporated in Table- 3 for the developed methods.

Table-3: Assay of solifenacin succinate in commercial dosage forms

\begin{tabular}{|c|c|c|c|c|c|c|c|}
\hline \multirow[t]{2}{*}{ Method } & \multirow{2}{*}{$\begin{array}{l}\text { Pharmaceutical } \\
\text { Formulation }\end{array}$} & \multirow{2}{*}{$\begin{array}{c}\text { Labeled } \\
\text { Amount } \\
(\mathrm{mg})\end{array}$} & \multicolumn{3}{|c|}{ PROPOSED METHOD } & \multirow{2}{*}{$\begin{array}{c}\text { Reference } \\
\operatorname{Method}^{7} \pm \text { S.D }\end{array}$} & \multirow{2}{*}{$\begin{array}{c}\% \\
\text { Recovery } \\
\text { obtained } \\
* *\end{array}$} \\
\hline & & & $\begin{array}{l}\text { Amount } \\
\text { Found* } \\
(\mathrm{mg}) \pm \text { S.D }\end{array}$ & $\begin{array}{c}\mathrm{t}- \\
\text { (value) }\end{array}$ & $\begin{array}{c}\mathrm{F} \\
\text { (Value) }\end{array}$ & & \\
\hline Method-I & \multirow[t]{2}{*}{ Oral Tablet } & \multirow[t]{2}{*}{10} & $9.98 \pm 0.124$ & 1.118 & 2.254 & \multirow[t]{2}{*}{$9.99 \pm 0.186$} & $99.49 \%$ \\
\hline Method-II & & & $9.99 \pm 0.147$ & 0.593 & 1.597 & & $100.00 \%$ \\
\hline
\end{tabular}

*Average \pm standard deviation of six determinations; $t$ and $\mathrm{F}$ - values refer to the comparison of the proposed method. Theoretical values at $95 \%$ confidence limits $\mathrm{t}=2.365$ and $\mathrm{F}=4.88 ; * *$ Average of six determinations.

\section{Chemistry of colored species}

The assumed reaction mechanism of the colored species formed in each proposed method has been presented in respective schemes given below.

\section{Method-I and II}

The carboxylate anion (negative charge) of solifenacin succinate is expected to attract the positive charge of methylene blue/ and Methylene Violet that behaves as a single unit (Ion-association complex) held together by electrostatic attraction (Figure-6) forming a colored complex that is measured spectrophotometrically.

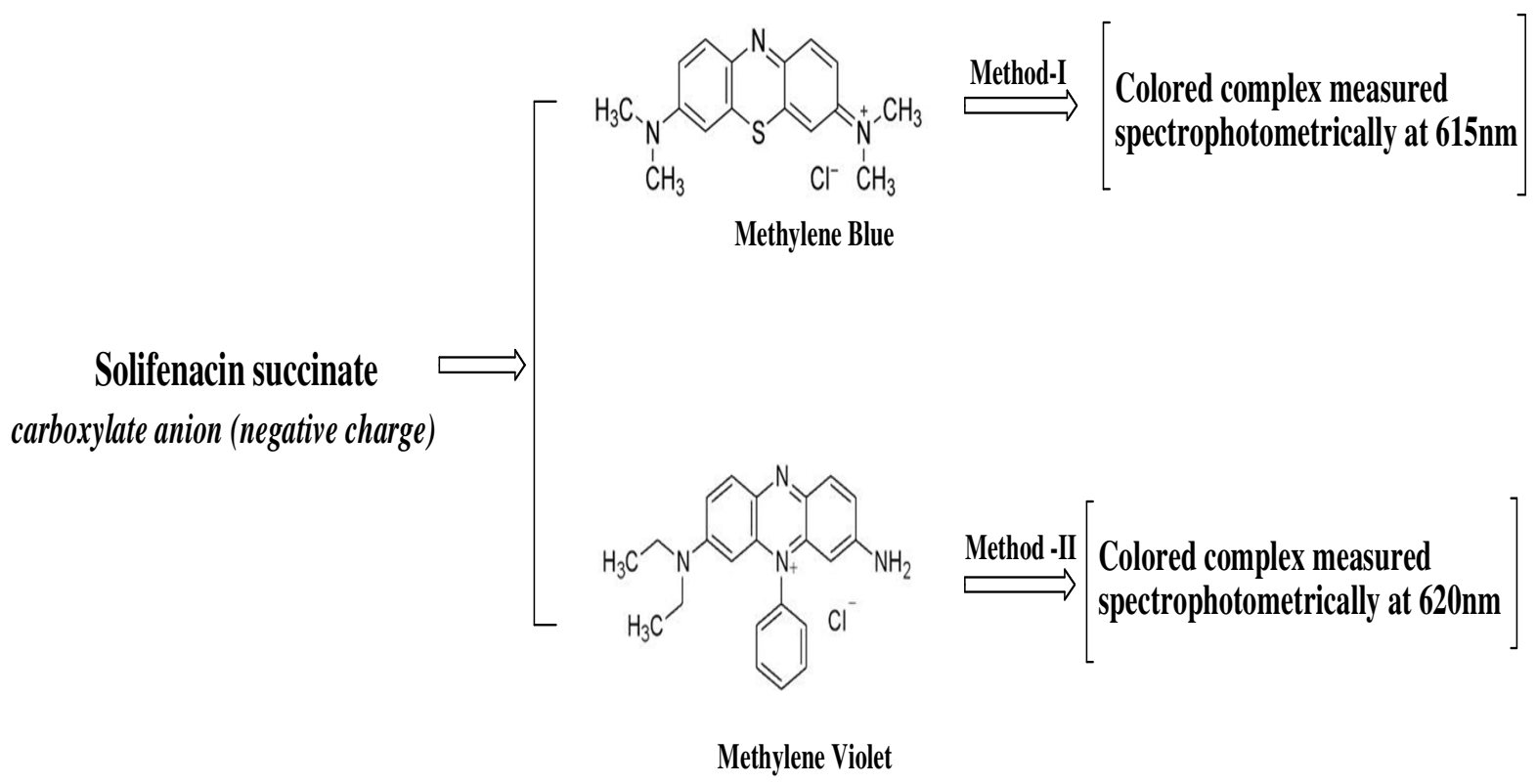

Fig.--6: Reaction analogy of solifenacin succinate with MB(Method-I) \&MV(Method-II)

\section{CONCLUSION}

Two new direct visible spectrophotometric methods (Method-I and II) were developed and validated for the estimation of Solifenacin succinate in oral tablets as per ICH guidelines. The developed methods (I and II) resulted in linearity in the range of $2-10 \mu \mathrm{g} / \mathrm{ml}$ with precision exemplified by relative standard 
deviation of 1.067 and $1.165 \%$ and with percentage mean recoveries in the range of 99.49 and $100.0 \%$ respectively. Basing on the validation results (Table-2) the proposed visible spectrophotometric methods can be used as substitute methods in the routine assay of solifenacin succinate in oral dosage formulations.

\section{ACKNOWLEDGEMENT}

The authors were thankful to Dr.Reddy Laboratories Ltd, Hyderabad (India) for affording the gifted sample of solifenacin succinate. The authors also thank M/s Fortune Pharma Training Institute, Hyderabad, and Department of Chemistry, Acharya Nagarjuna University,Guntur(AP) for providing necessary lab facilities to complete this research.

1. http://en.wikipedia.org/wiki/Solifenacin.

2. http://www.drugbank.ca/drugs/DB01591.

3. Budavari, The Merck Index, $14^{\text {th }}$ ed., Merck \& Co. Inc., White house station, NJ, p.1484 (2006).

4. Solifenacin Succinate API Monograph, EP 8.6.

5. G. Divya Teja, C. H. Devadasu, P. Srinivasa Babu and P. Ravi Sankar, Journal of Chemical and Pharmaceutical Sciences,6(3),195(2013).

6. R. Seetharaman and K.S Lakshmi, International Journal of Research in Pharmaceutical and Biomedical Sciences, 2(3),1052(2011).

7. Lokesh Singh and Sanju Nanda, Pharmaceutical Methods, 2(1), 21(2011).

[RJC-1812/2017] 